\title{
EVALUATING THE EFFECTIVENESS OF A WORKSITE WELLNESS PROGRAM
}

\author{
Barbara Mazur*, Marta Mazur-Małek**
}

\begin{abstract}
Background. Wellness programs have been implemented and developed for quite some time already, especially in companies abroad. They become ever more present in Polish companies as well, yet the available literature - both foreign and Polish - is rather scarce. There appears to be a lack of sources which present tools to evaluate the effectiveness of worksite wellness programs in a synthetic and especially review-like manner.
\end{abstract}

Research aims. The research problem is to determine methods to evaluate the effectiveness of worksite wellness programs. Those programs are implemented in order to achieve two objectives: enhance the employee's wellbeing and improve the economic outcomes of the whole company. The issue of implementing and measuring a worksite wellness program's effectiveness is then inevitable. The main objective of this article is to examine what kind of tools can be applied in the process of evaluating the effectiveness of worksite wellness programs.

Methodology. The article is based on a review and analysis of the available literature.

Key findings. The effectiveness of a worksite wellness program can depend on such variables as the employee's gender, size of the company, or program type. The effectiveness of a worksite wellness program seems to depend as well on factors such as top management engagement and support, setting of clear objectives and achievable aims, effective communication, and measurement and evaluation procedures.

Keywords: organisations, management of wellness programs, effectiveness, measurement.

\section{INTRODUCTION}

Wellness in the workplace has been an increasingly valid topic of discussion. It has been long recognised that healthy and contented workers exhibit a higher productivity rate. Another benefit for the

* Lublin University of Technology. E-mail: b.mazur@pollub.pl

** University of Tartu, Estonia. E-mail: mazur.malek@yahoo.com 
company, resulting from the happiness of its workers, is the reduced cost of employee healthcare and lowered absenteeism. Being aware of that, numerous companies implement special programs aiming at improving employee health and wellbeing and, in that way, making them more effective and efficient. However, as to what worksite wellness actually is, Guazzi et al. (2014) prove that there is no officially approved definition and understanding of Worksite Health and Wellness (WHW). To illustrate this phenomenon, the authors focus on the situation in the European Union. They name the main actors in the worksite wellness fields, which are the European Agency for Safety and Health at Work (EU OSHA), European Network for Workplace Health Promotion, and Wellness International, and demonstrate different approaches to worksite wellness. Guazzi et al. (2014) state that EU's variety in understanding WHW comes from the differences in the legislation and state's position in particular member states. Therefore, worksite wellness programs take all different forms: from individual coaching, through group actions, to web-based learning. As a consequence, the variety in understanding worksite wellness motivates the numerous tools available for measuring the effectiveness of wellness programs.

\section{The reasons behind introducing worksite wellness programs}

If, on average, an employee spends about 40 hours at work per week, it becomes obvious that work may easily influence private life. Professional career constitutes a significant part of life for the bigger part of the society and therefore the issues of health and happiness should be paid considerate attention to. Monkevičius (2014) introduces the Quality of Working Life index, showing that work and quality of life are explicitly interconnected. The author defines the Quality of Working Life as "a level of well-being at work that depends on the relation between the whole of the factual working conditions and personality" (Monkevičius, 2014, p. 8). The indicator shows the level of happiness at work. The author argues that the happiness component is crucial in the Quality of Working Life. Moreover, the framework focuses on promoting conditions which satisfy workers' physical, social, economic, and psychological needs. Quality of Working Life, however, should be also linked directly to organisational success 
and corporate objective-meeting. It shows a mutually beneficial relationship between the company's success and the quality of work for employees. In comparison to the employees that are less happy at work, the more satisfied ones demonstrate less absenteeism and better health (Monkevičius, 2014, p. 21).

In today's society, civilization and chronic diseases constitute one of the main sources of health problems. It has been very problematic, especially for the working part of the population as well as the employers. Wein (2015) states that $45 \%$ of the American population has at least one chronic disease. Chronic diseases have been found very costly, especially for the employers. For this reason, among others, worksite wellness programs have been growing ever more popular in the corporate world.

Wein (2015) cites Harvard University's study showing that worksite wellness programs can bring about six-fold Return on Investment (ROI). Most of the money 'gained' comes from cutting healthcare costs. For instance, the reason behind having a primary and urgent care centre on-site a company is that it should help to reduce costs of hospitalisation and referrals to specialists, according to Khoury. Corporate wellness centres keep workers safe during work and aim to speed up employees' returns after an injury or illness. From the company's perspective, upkeeping employees' wellness is crucial in order to improve the work effectiveness, increase the number of work activities performed, implement more effective conflict management strategies, enhance interpersonal relations at work, and increase employer loyalty, according to Ford et al. (2011).

The indirect cost of lost time is also reduced due to an easier access to on-site health amenities, and reducing the recovery time by offering additional treatments at work.

\section{The history of the worksite wellness program}

Khoury links the beginnings of worksite wellness with the emphasis on preventing and curing occupational injuries. After World War II, gymnasiums were being built in some of the bigger companies as the executives recognised the value of staying fit. At first, those facilities were available to top management, but then the idea spread and gymnasiums became more and more prominent among workers, especially in the 1970s. However, the very beginnings of 
worksite wellness happened already in the 1930s, when Hershey Foods offered a complete recreation centre, along with a swimming pool, to its employees. In the 1950s and 60s companies like Texas Instruments, Rockwell, or Xerox, followed with their own employee fitness programs.

It is believed that the healthcare reform legislation in the United States has encouraged implementing worksite wellness programs (Beck et al., 2016). Those programs have developed largely due to the cost containment needs and the worksite health promotion movement efforts. In 1970 The Occupational Safety and Health Administration was established as a part of the Department of Labor in the United States, which main aim was to focus on avoiding workplace accidents and work-related illnesses. The programs themselves were introduced on a larger scale in the mid-1970s, according to Reardon (1998). The author claims that they represent the shift of responsibility for health from the government to the employers, from healthcare to its consumers. Reardon (1998) states that technological advances have made it easier for employees to be less mobile. The author shows that a less mobile lifestyle and an ever-growing base of diseases result in an increased stress on the healthcare system, which in effect means that the healthcare system will need more funds. Employers finance the healthcare budget in a considerate part, therefore, it has been in their interest to decrease healthcare costs.

In the 1980s employee wellness programs became more holistic, offering help with smoking cessation, weight management, and stress management (Khoury). The end of the $20^{\text {th }}$ century was the time when multiple corporations began developing more comprehensive employee wellness programs. According to statistics, health promotion strategies were being used by over a half of global employers in 2014. One in three of them has invested in entire wellness programs (History of Wellness). Babu et al. (2014) mention one of the contemporary American actions to improve the health of the society overall - The Healthy People 2020, whose goal is to maximise the access to fitness facilities for workers. The lack of adequate physical activity is believed to still be one of the most serious health problems for the employees in developed countries, nowadays. 


\section{Worksite wellness programs content}

According to up-to-date research, worksite wellness programs target mostly reversible or alterable health issues like smoking, weight loss, or stress management (Khoury). Nowadays, employee wellness programs offer such services as: pharmacy services urgent care, preventive measures, wellness coaching, diet planning, long-term disease management, stress management programs, physical therapy and rehabilitation, fitness programs, dental health services, vision care, medical check-ups, and many others.

When it comes to the introduction of worksite wellness programs, there exist best practices often brought up by numerous authors. Wein (2015) underlines the importance of a proper assessment of the needs and resources available while introducing a worksite wellness program. Babu et al. (2014) states that the following best practices help to ensure maximum success of the workplace wellness program:

- Assessment

It is necessary to properly assess the needs and objectives of the program before it starts. The needs are to be understood mainly as the employees' needs. It is therefore advisable to research what the main problems among workers are and assess resources to minimise them.

- Planning

Among planning practices, the authors advise setting up a team for the program (designated people responsible for the program's actions), introduce wellness ambassadors, create written documents, ensure great communication and training.

- Implementation

During this phase, opportunities to contact and educate all stakeholders should be exploited.

- Evaluation

Most of the evaluation should be based on the employees' feedback. It is their health needs that the program should satisfy and they can be a crucial source of information for program evaluation. The authors stress the need for regular reassessing (every 2-3 years). 


\section{The human perspective on a healthy workplace}

The psychological aspect of worksite health has been a topic of interest for some time now. Already in the early 1900s, work-health relationship was investigated and discussed (Day, 2015). As an example, Day also brings out programs targeting the psychological wellness of employees introduced in the United States, like Achieving a Better Life Experience (ABLE) act and Civility, Respect, and Engagement in the Workplace (CREW) program. Those projects aim at making the workplace more likeable for the employees. The author brings up an interesting idea regarding job stress. Many programs have been focusing on workplace injuries. Studies show that a considerate amount of workplace injuries is caused by stress. Stress can be the result of a challenging deadline or a demanding boss. Therefore, worksite wellness programs should target not only the employees, but also (or perhaps especially) top-level managers and business owners. Worksite wellness should be the aim for all of the stakeholders in a company. Mental health training can be helpful in building awareness and understanding of workplace psychological health issues (Day, 2015).

A caring company is proved to achieve more worksite wellness than one with a set employee wellness program. That can happen due to the complexity of the human being psychology. It is not just a well though-through wellness program that will help employees feel good at work. Often it is the 'intangibles' that matter most in creating employee wellness. Research (Everyday Health Inc. \& Global Wellness Institute, 2016) shows that honest communication, friendly atmosphere, and teamwork spirit have been perceived crucial in building workplace wellness. "Unlocking the Power of Company Caring," a study conducted in 2016, argues that the relationship between employees and employers is a human one. It requires personalised attention and flexibility. The study showed a discrepancy between what is believed to impact employee wellness by companies and what the employees themselves perceive as positively influencing their workplace wellness. Therefore, companies need to focus more on what the employees themselves perceive helps them in the work environment. Moreover, the role of managers and leaders in setting positive role-models and encouraging healthy lifestyle changes was mentioned. 
The need to tailor the form and the content of worksite wellness programs to each company's needs has been essential, according to numerous researchers. After Greiner, Reardon (1998) argues that it is personal motivation rather than health education that drives participation in fitness activities. Therefore, worksite wellness programs should help to find a way to aid creating personal motivation for healthy lifestyle changes.

What is more, Beck et al. (2016) claim that tailored communication may improve the effectiveness in increasing participation in worksite wellness programs. The authors argue for tailoring also when it comes to the physical activity promoted. Namely, some workers have a 'sitting' job and will, therefore, be interested in a different type of physical activity than those who are much more mobile during work. This understanding tailoring will aid to increase the benefits, perceived by the participant, of engaging in the program. This, in turn, will allow the participation rates to increase.

\section{Evaluation of the effectiveness of worksite wellness programs}

It is recognised that the measurement of wellbeing at work is poorly represented in research in relation to the measurement of wellbeing in private life.

The central aspect of wellbeing at work is work-related affective wellbeing. That is why wellbeing at work can be considered analogically to the concept of subjective wellbeing, and described as a balance of emotions felt during work, which allows evaluating it as valuable. The analysis of wellness and factors associated with work wellbeing is a vital matter for discussion. Equally important is the study of the effectiveness of wellness programs, which aim is to enhance work wellbeing for the employees.

Monkevičius (2014) argues for a systematic approach to the evaluation of worksite wellness programs' effectiveness. The author introduces many systems of wellness program effectiveness evaluation. For instance, the Job Quality Index (JQI) is described in detail. It is a measurement consisting of six differently weighted dimensions: wages, non-standard forms of employment, work-life balance and working time, working conditions and job security, access to training and career advancement, and collective interest representation and 
voice/participation (Monkevičius, 2014, p. 18). Moreover, Monkevičius brings up a tool by Clark used for measuring employee satisfaction with job quality. This framework is divided into six groups of indicators: pay, work hours, possibilities for future development, level of job difficulty, job content: interest, prestige and independence, and interpersonal relationships (with co-workers and management). Moreover, the author suggests their own new formula to measure the Quality of Working Life (QWL) (Monkevičius, 2014, p. 16). It reads as follows:

$$
\mathrm{QWL}=\mathrm{H} \times(\mathrm{O} \times \mathrm{S}-\mathrm{I})
$$

Where:

$\mathrm{H}$ - happiness, $\mathrm{O}$ - objective quality of work, $\mathrm{S}$ - subjective satisfaction, I - importance of the work.

In order to determine the level of objective quality of work, subjective satisfaction, and the importance of work, a refined set of questions is presented. It includes four main parts, each of which is constructed from numerous questions, for instance about Work-Life Balance or working relationships.

Werneburg et al. (2011) focus on the specific examples of a wellness program - stress management. The authors make a connection between absenteeism at work and high stress levels (Werneburg et al., 2011, p. 356). Stress management tends to be a valuable part of worksite wellness programs. The authors bring up numerous examples of corporations which have already implemented a stress management program, like General Mills, DowChemical Company, Union Pacific Railroad, John Wiley \& Sons, Ltd., Duke University, Cianbro, or Ernst \& Young (Werneburg et al., 2011, p. 357). A measurement tool is also introduced. The Life Experiences Survey is a tool evaluating the experiences undergone throughout the course of the last 12 months. LES helps to determine the current stress level based on a year's experience. Questions include emotional and physical wellness, like questions about marriage or the quality of sleep, among many others. The most stressful factor turned out to be a change in the work environment (Werneburg et al., 2011, p. 361). The survey shows how much influence a workplace possesses on an employee's health. The research results prove a difference in the stress levels among male and female respondents and different impacts of the program on the levels between 
those two groups. The authors argue for a gender-specific wellness program to be introduced in companies. They stress the importance of tailoring the program before implementation.

Keller et al. (2009) examined whether the size of the company and employees' gender influence the impact of the worksite wellness program. The program effectiveness was measured based on six criteria: fitness, nutrition and weight, blood pressure and stress, substance abuse, smoking, and safety (Keller et al., 2009, p. 295). Additionally, the employees' gender and the size of the company were taken into consideration. The effectiveness study was based on the percentage of the company's cost reduction regarding expenses for employee health. The results have shown a significant reduction in the costs, deeming the programs effective. Depending on the criteria of investigation, some programs seemed more effective among bigger companies and some among smaller. Similar results were related to employee gender (Keller et al., 2009, p. 300). Some programs worked better with female employees, and some with male. This study, too, shows that choosing a worksite wellness program tailored for the size and target group within the company matter for its overall effectiveness.

Osilla et al. (2012) offer a theoretical review of the worksite wellness program impacts on companies in general. The authors focused on healthy behaviours, psychological improvements, cost of healthcare for the company as well as change in absenteeism levels. They aimed at establishing the characteristics of worksite wellness programs, their impact on outcomes, and initiatives to take-up the program and their impact; the results showed the program's effectiveness in about $75 \%$ of the cases (Osilla, 2012, p. 68). The most effective appeared to be the programs aiming at decreasing absenteeism and employee healthcare cost. This study shows a rather significant difference in the types of worksite wellness programs, their aims, and outcomes.

Terry et al. (2008) conducted a research of worksite wellness programs among companies with common practices as well as best practices. The study aimed at finding differences in participation rates in various sub-programs (like health assessment, health coaching, etc.) and their impacts among companies applying common practices and best practices (Terry et al., 2008, p. 633). The results of the program quality were obtained using the Health Enhancement Research Organization (HERO) scorecard (Terry et al., 2008, p. 634). The tool's goal is to facilitate the design of the worksite wellness 
program, quality gap assessment, and program evaluation. The results showed that among the best practice companies, the effectiveness of wellness programs was higher. It is assumed to be a consequence of good communication and clearly set objectives, effective incentives introduction, and evaluation techniques (Terry et al., 2008, pp. 634, 637). Top management's involvement in the implementation and success of the worksite wellness program turned out to be crucial. Moreover, the authors share some interesting insights about the problems of implementing and managing a wellness program at work. They stress the need to clearly define the budget and set achievable and measurable goals, which best practice companies seem to have mastered compared to common practice companies (Terry et al., 2008, p. 634). There is a need for tailoring the programs, but also for setting appropriate evaluation schemes and tools. The ones introduced here can be understood as a pool of potential possibilities to look through. The method chosen must take into consideration such factors as the specificities of the companies and its workers.

There is no 'one fits all' kind of program. The majority of worksite wellness specialists emphasise the need to tailor the programs to the company's needs, and take into consideration such factors as the size of the company, number of employees engaged, communication techniques, gender of the employees, and even generation.

\section{CONCLUSION}

Most of the analysed scientific articles highlight the difficulty of accurately evaluating worksite wellness program's effectiveness. This, according to the majority of the authors, is caused by a lack of a common evaluation scheme. Nonetheless, numerous tools have been presented and shortly elaborated on. The concept of Quality of Working Life, as a value of happiness, objective quality of work, subjective satisfaction, and work importance, has been introduced. The Job Quality Index appears as another tool to evaluate work quality. Moreover, the HERO scorecard and Life Experience Survey can be applied in the process of program evaluation. Some of the authors conclude that it is easier to evaluate the effectiveness of a risk-specific sub-program rather than the comprehensive one. In other words, it appears to be easier to evaluate the results of (for instance) the smoking cession 
program than the whole worksite wellness one. What seems to be the most important, however, is the conclusion that the program chosen should be tailored to the needs of the company. There exists no 'one fits all' worksite wellness program. The effectiveness can depend on such variables as the employee's gender, size of the company, or type of a wellness program applied. Worksite wellness programs seem to be a value option for companies looking to decrease employee healthcare costs and lower absenteeism levels. Those aims will be fulfilled successfully, given that the process is systematised and thought-through. The effectiveness of a worksite wellness program seems to depend on factors such as top management involvement and support, setting of clear objectives and achievable aims, effective communication, and measurement and evaluation procedures.

\section{REFERENCES}

Babu, A.S., Madan, K., Veluswamy, S.K., Mehra, R. \& Maiya, A.G. (2014). Worksite health and wellness programs in India, Progress in Cardiovascular Diseases, 56(5), 501-507, doi:10.1016/j.pcad.2013.11.004

Beck, A.J., Hirth, R.A., Jenkins, K.R., Sleeman, K.K. \& Zhang, W. (2016). Factors associated with participation in a university worksite wellness program, American Journal of Preventive Medicine, 51(1), 1-11 . doi:10.1016/j. amepre.2016.01.028

Day, A. (2015, Autumn). Developing psychologically healthy workers and healthy workplaces. Psynopsis, Le Magazine Des Psychologues Du Canada, 11-13.

Everyday Health Inc. \& Global Wellness Institute (2016). Unlocking the Power of Company Caring (PDF). Global Wellness Summit.

Ford, M.T., Cerasoli, C.P., Higgins, J.A. \& Decesare, A.L. (2011). Relationships between psychological, physical and behavioral health and work performance: A review and meta-analysis, Work \& Stress, 5, 185-204.

Guazzi, M., Faggiano, P., Mureddu, G.F., Faden, G., Niebauer, J. \& Temporelli, P.L. (2014). Worksite health and wellness in the European Union, Progress in Cardiovascular Diseases, 56(5), 508-514, doi:10.1016/j.pcad.2013.11.003

History of Wellness (n.d.). Retrieved October 31, 2016, from http://www.globalwellnessinstitute.org/history-of-wellness/

Keller, P.A., Lehmann, D.R. \& Milligan, K.J. (2009). Effectiveness of corporate well-being programs: A meta-analysis, Journal of Macromarketing, 29(3), 279-302, doi:10.1177/0276146709337242 
Khoury, A. (n.d.). The Evolution of Worksite Wellness. Retrieved November 1, 2016, from http://www.corporatewellnessmagazine.com/worksite-wellness/ the-evolution-of/

Greiner, P. A. (1987). Nursing and worksite wellness. Holistic Nursing Practice,2(1), 53-60. doi:10.1097/00004650-198711000-00009

Monkevičius, A. (2014). Quality of working life concept and empirical indicators, Intellectual Economics, 8(1), 8-24, doi:10.13165/ie-14-8-1-01

Osilla, K.C., van Busum, K., Schnyer, C., Larkin, J.W., Eibner, C. \& Mattke, S. (2012). Systematic review of the impact of worksite wellness programs, The American Journal of Managed Care, 18(2), E68-E81. Retrieved April 20, 2016.

Reardon, J. (1998, May/June). The history and impact of worksite wellness, Nursing Economics, 16(3), 117-121. Retrieved October 31, 2016, from http://search. proquest.com/openview/e29c462f6a0ab35594d2acc7a168c663/1?pq-origsite $=$ gscholar

Terry, P.E., Seaverson, E.L., Grossmeier, J. \& Anderson, D.R. (2008). Association between nine quality components and superior worksite health management program results, Journal of Occupational and Environmental Medicine, 50(6), 633-641, doi:10.1097/jom.0b013e31817e7c1c

Wein, D. (2015). Worksite wellness programs offer valuable benefits to both employers and employees, Employment Relations Today, 41(4), 35-43, doi:10.1002/ ert. 21472

Werneburg, B.L., Herman, L.L., Preston, H.R., Rausch, S.M., Warren, B.A., Olsen, K.D. \& Clark, M.M. (2011). Effectiveness of a multidisciplinary worksite stress reduction programme for women, Stress and Health, 27(5), 356-364, doi:10.1002/smi. 1380 


\title{
OCENA SKUTECZNOŚCI PRACOWNICZYCH PROGRAMÓW WELLNESSOWYCH
}

\begin{abstract}
Abstrakt
Tło badań. Z perspektywy organizacji wspieranie dobrostanu pracowniczego ma kluczowe znaczenie, ponieważ ma on wpływ na podniesienie poziomu efektywności pracy, zwiększenie jakości wykonywanych czynności zawodowych, poprawienie stosunków interpersonalnych w środowisku pracy oraz zwiększenie lojalności wobec pracodawcy. Programy mające na względzie dobrostan pracowników pojawiły się w zagranicznych firmach wiele lat temu. Coraz częściej pojawiają się także w polskich przedsiębiorstwach. Jednakże w ślad za nimi nie idzie liczba badań odnoszacych się do tego zagadnienia. Brakuje zwłaszcza publikacji na temat metod mierzenia skuteczności tych programów.
\end{abstract}

Cel badań. Głównym celem artykułu jest wskazanie narzędzi użytecznych w procesie określania efektywności stosowanych programów. Artykuł ma charakter przeglądowy. Prezentuje on koncepcję dobrostanu pracowniczego, korzyści wynikające dla firm z wprowadzania programów mających przyczynić się do podniesienia poziomu dobrostanu pracowników oraz wskazywane w literaturze sposoby mierzenia ich skuteczności. Artykuł zawiera również wnioski, z których wynika przede wszystkim istotność wagi czynnika ludzkiego w przedstawianym procesie.

Metodologia. Artykuł oparty jest na przeglądzie dostępnej literatury.

Kluczowe wnioski. Skuteczność programu wellness może zależeć od zmiennych, takich jak płeć pracowników, wielkość firmy czy typ programu. Skuteczność funkcjonalnego programu dobrostanu pracowniczego wydaje się zależeć od czynników takich jak zaangażowanie i wsparcie kadry menedżerskiej, skuteczna komunikacja oraz wdrożone procedury pomiaru i oceny.

Słowa kluczowe: Organizacja, zarządzanie programem wellnessowym, efektywność, mierzenie. 